\title{
病害虫の発生と防除の概況
}

\section{1年 九州沖䋲地域における主な病害虫の発生概況}

（病害虫発生予察情報＼cjkstart注意報・警報および特殊報）

*病害虫発生予察情報・発表月日（かっこ内）：警報（太字）；注意報（細字）；特殊報（下線付き）

\begin{tabular}{|c|c|c|c|}
\hline & 稲・麦・畑作物 & 野菜・花き & 果樹·茶樹·特用作物 \\
\hline $\begin{array}{l}\text { 福 } \\
\text { 岡 } \\
\text { 県 }\end{array}$ & $\begin{array}{l}\text { ・水稲 : イネ縞葉枯病（ヒメトビウン } \\
\text { 力 })(4 / 20) \\
\text { ·水稲 }: \text { いち病（穂いもち） }(8 / 18)\end{array}$ & $\begin{array}{l}\cdot \text { ダリア：PSTVd }(3 / 31) \\
\cdot \text { イチゴ : 炭疽病 }(7 / 28)\end{array}$ & 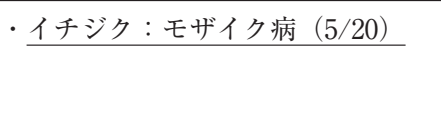 \\
\hline 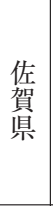 & $\begin{array}{l}\text { - 普通期水稲 : いもち病（穂いもち） } \\
\quad(8 / 24)\end{array}$ & ・キク：キク荎えそ病（CSNV） (8/19) & 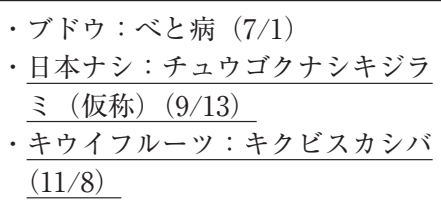 \\
\hline $\begin{array}{l}\text { 長 } \\
\text { 崎 } \\
\text { 県 }\end{array}$ & & $\begin{array}{l}\text { ・タマネギ : ベと病 }(3 / 31) \\
\text { ・キク : キク茎えそ病 }(6 / 17) \\
\text { ·イチゴ (育苗箱) : 炭疽病 }(7 / 19)\end{array}$ & •ブドウ：べと病（7/19） \\
\hline $\begin{array}{l}\text { 熊 } \\
\text { 県 }\end{array}$ & ・早植水稲：いもち病（8/12） & $\begin{array}{l}\text { ・ バレイショ：ジャガイモシストセン } \\
\text { チュウ }(8 / 18) \\
\text { • トマト: 黄化病 }(10 / 6)\end{array}$ & ·チャ:チャトゲコナジラミ $(11 / 30)$ \\
\hline $\begin{array}{l}\text { 大 } \\
\text { 分 } \\
\text { 県 }\end{array}$ & & & \\
\hline $\begin{array}{l}\text { 宮 } \\
\text { 崎 } \\
\text { 県 }\end{array}$ & $\begin{array}{l}\text { ·早期水稲：いもち病(穂いもち) (6/16) } \\
\text { ·普通期水稲：いもち病（穂いもち） } \\
\quad(8 / 10)\end{array}$ & $\begin{array}{l}\text { • ピーマン : 斑点病 }(1 / 25) \\
\text { •イチゴ (親株) : 炭疽病 }(6 / 24) \\
\text { • キュウリ、メロン:黄化えそ病 }(10 / 20)\end{array}$ & \\
\hline $\begin{array}{l}\text { 鹿 } \\
\text { 览 } \\
\text { 島 } \\
\text { 県 }\end{array}$ & ・さとうきび : イネョトウ（7/7） & $\begin{array}{l}\text { ・トマト：茥えそ病（仮称） }(5 / 2) \\
\text { ・イチゴ : うどんこ病 }(11 / 30)\end{array}$ & ·マンゴー:マンゴーキジラミ $(2 / 25)$ \\
\hline $\begin{array}{l}\text { 沖 } \\
\text { 縄 } \\
\text { 県 }\end{array}$ & ・さとうきび : イネヨトウ (6/29) & & \\
\hline
\end{tabular}

